\title{
IMPROVING HATCHABILITY OF LATE EGGS LAID WITH DIETARY SUPPLEMENTAL OF PYRIDOXINE AND FOLIC ACID OF FAYOUMI STRAIN
}

\author{
Wagdy, A.Z.; S.A.M.Shabaan and M.A. A. Abd El-Mageed
}

Animal Prod. Res. Inst., Agric. Res. Center, Minist. of Agric, Doki, Giza, Egypt.

\begin{abstract}
An experiment was carried out at the poultry research station, El-Fayoum, Animal Production Research Institute, Agriculture Research Center, Ministry of Agriculture, Dokki, Egypt, during the year 2005. A total number of 144 hens and 12 cocks from Fayoumi strain of 48 wk old to determine whether hatchability can be improved by using folic acid or pyridoxine supplementation in diets during the late stages of laying season. Birds were divided to 3 equal groups ( 48 hens +4 cocks each) of 4 replicates each. A corn-soybean meal basal experimental layer diet was formulated of being $16.5 \%$ CP \& $2700 \mathrm{kcal} . \mathrm{ME} / \mathrm{kg}$ diet. Three dietary treatments were used: an unsupplemented practical corn-soybean meal basal diet; the basal diet supplemented with $1 \mathrm{mg}$ folic acid $6 \mathrm{mg}$ pyridoxine $/ \mathrm{kg}$ of diet. Response criteria included egg production-related traits, egg fertility and hatchability and egg quality traits.

The following results were obtained:

- Hens fed folic acid-supplemented diet showed the highest feed intake. Hens fed pyridoxine-supplemented diet resulted in significantly higher egg weight, egg number and egg mass as compared to those fed control diet.

- Hens fed folic acid-supplemented diet gave the highest fertility and hatchability \% followed by those fed pyridoxine-supplemented diet as compared to those fed control diet.

- Hens fed folic acid-supplemented diet gave the highest egg shape index however, hens fed pyridoxine-supplemented diet gave similar egg shape index as compared to those fed control diet. Albumin \% and albumin height were not significantly affected by different treatments during the different experimental periods.

From the nutritional point of view, under the present experimental conditions, it is advisable to add $1 \mathrm{mg}$ folic acid or $6 \mathrm{mg}$ pyridoxine $/ \mathrm{kg}$ of laying hen diet. Such practice helps in improving laying performance, fertility, hatchability and egg quality and seems to be advantageous in decreasing chick abnormalities.
\end{abstract}

\section{INTRODUCTION}

The egg production of a chicken is a result of nutritional status that acts to allow the chicken to express fully its genetic potential. Vitamins are involved in most metabolic processes and are an integral part of embryonic development, therefore the consequence of suboptimal levels of these nutrients in commercial diets are known to result in negative responses to both parent and offspring performance.

Pyridoxine is one of the three major chemical forms of vitamin $B_{6}$ that is a water-soluble vitamin (Bender,1989). It performs a wide variety of functions in body and is essential for good health. It is a coenzyme for enzymes involved in amino acid metabolism. It is also essential for red blood cell metabolism. The nervous and immune systems need vitamin $B_{6}$ to function efficiently (Trakatellis et al., 1997) and it is also needed for the 
conversion of tryptophan (an amino acid\} to niacin, a vitamin, (Shibata et al., 1995). Vitamin $B_{6}$ is needed to make hemoglobin that carries oxygen to tissues. It also helps increase the amount of oxygen carried by hemoglobin. A vitamin $B_{6}$ deficiency can result in a form of anemia (Leklem et al., 1999) that is similar to iron deficiency anemia. Vitamin $\mathrm{B}_{6}$, through its involvement in protein metabolism and cellular growth, is important to the immune system. It helps maintain the health of lymphoid organs (thymus, spleen, and lymph nodes) that make white blood cells. Animal studies show that a vitamin $\mathrm{B}_{6}$ deficiency can decrease your antibody production and suppress immune response (Chandra and Sudhakaran, 1990). Vitamin B 6 also helps maintain blood glucose within a normal range. When caloric intake is low, body needs vitamin $B_{6}$ to help convert stored carbohydrate or other nutrients to glucose to maintain normal blood sugar levels.

House et al., (1999) reported that folic acid status is linked to increased serum levels of the sulfur amino acid homocystine, due to the role of folic acid that plays as co-factor in the remethylation of homocystine to form methionine. House et al., (2002) reported that increasing the folic acid content of eggs make the egg as an important source of dietary folic acid lead to consumer acceptance of this commodity as a healthful product.

Egg production depends on many characters such as age that have a negative effect on productive and reproductive performance of layer hens especially at the end of production cycle. Fayoumi $(F)$ strain is well known and wide distributed in Upper Egypt and its characteristics of egg production and egg quality are sill low.

Therefore, the present work was carried out to study the effect of supplementing pyridoxine and folic acid into diet on productive performance, egg quality and egg components of Fayoumi hen layers as a local Egyptian strain, during their late stage of production.

\section{MATERIALS AND METHODS}

The experimental work of the present study was carried out at the Poultry Research Station, Fayoum, Animal Production Research Institute, Agriculture Research Center, Ministry of Agriculture, Dokki, Egypt. The experiment was started in January 2005 and terminated 12 weeks later.

\section{Experimental birds and diets}

A total number of 144 hens and 12 cocks from Fayoumi strain of 48 wk old were fasted overnight, individually leg-banded, weighed to the nearest $1 \mathrm{~g}$ and randomly divided to 3 equal groups (48 hens +4 cocks each) of 4 replicates each. The initial live body weight (LBW) was nearly equal in all groups. The groups were randomly housed in suitable floor laying pens with chopped wheat straw litter.

A corn-soybean meal basal layer diet was formulated (16.5\% CP \& $2700 \mathrm{kcal} . \mathrm{ME} / \mathrm{kg}$ diet). The composition and chemical analysis of the experimental diets is presented in Table (1). The first diet was considered as a control diet and contained the NRC (1994) recommended level of folic acid and pyridoxine. The second treatment group was supplemented $1 \mathrm{mg}$ folic $\mathrm{acid} / \mathrm{kg}$ diet. The third ones was supplemented $6 \mathrm{mg}$ pyridoxine $/ \mathrm{kg}$ diet. 
Table (1): Composition and calculated analysis of the experimental starter-grower and layer basal diets.

\begin{tabular}{|l|c|}
\hline \multicolumn{1}{|c|}{ Ingrediens } & (\%) \\
\hline Yellow Corn, ground & 62.77 \\
\hline Soybean meal(44\% CP) & 26.04 \\
\hline Wheat bran & 1.12 \\
\hline Dicalcium phosphate & 1.54 \\
\hline Limestone & 7.77 \\
\hline Common salt (NaCl) & 0.40 \\
\hline Premix ${ }^{*}$ & 0.30 \\
\hline DL-Methionine & 0.06 \\
\hline Total & 100 \\
\hline Calculated values (\%) & 16.5 \\
\hline CP \% & 2700 \\
\hline ME (kcal/kg) & 3.46 \\
\hline CF \% & 2.82 \\
\hline EE \% & 3.33 \\
\hline Ca \% & 0.41 \\
\hline Av. Phosphorus \% & 0.92 \\
\hline L-Lysine \% & 0.35 \\
\hline DL-Methionine \% & 0.63 \\
\hline Methionine + Cyst \% & 0.17 \\
\hline Sodium \% & \\
\hline
\end{tabular}

*The premix (Vit. \& Min.) was added at a rate of $3 \mathbf{~ k g}$ per ton of diet and supplied the following (as mg or I.U. per kg of diet): Vit. A 12000 I.U., Vit. D 32000 I.U., Vit. E $40 \mathrm{mg}$, Vit. K 4 mg, Vit. $B_{1} 3 \mathrm{mg}$, Vit. $B_{2} 6 \mathrm{mg}$, Vit. $B_{6} 4 \mathrm{mg}$, Vit. $B_{12} 0.03 \mathrm{mg}$, Niacin $30 \mathrm{mg}$, Biotin $0.08 \mathrm{mg}$, Pantothenic acid $12 \mathrm{mg}$, Folic acid $1.5 \mathrm{mg}$, Choline chloride $700 \mathrm{mg}$, Mn $80 \mathrm{mg}$, Cu $10 \mathrm{mg}$, Se $0.2 \mathrm{mg}$, I $40 \mathrm{mg}$, Fe $40 \mathrm{mg}, \mathrm{Zn} 70 \mathrm{mg}$ and Co $0.25 \mathrm{mg}$.

\section{Management and vaccination:}

Birds in all experimental treatments were kept as possible under similar managerial and hygienic conditions. The experimental layer diet were weekly mixed and offered, in mash form. Also, fresh clean water was freely available and artificial lighting was provided 16 hours per day during the experimental period.

Birds were vaccinated according to the vaccination program of egg production flocks present at the Poultry Research Station, Fayoum, Animal Production Research Institute, Agriculture Research Center, Ministry of Agriculture, Egypt.

\section{Measurements and methods of interpreting results}

The following criteria were measured and/or calculated in the present study:

1- Egg production-related traits: Egg number (EN), egg weight (EW), egg mass (EM), feed intake (FI) and feed conversion (FC) $(\mathrm{kg}$ feed $/ \mathrm{kg}$ egg) were recorded for each hen for each 4-weeks period from 48 to 60 weeks of age.

2- Egg quality traits: Percentages of yolk, albumin and shell were calculated. Egg shape index (ESI) was estimated as the ratio of the egg maximum 
Wagdy, A.Z. et al.

width to its length. Shell thickness was estimated on the membraneless shell by using Ames shell thickness gauge to the nearest $\mu \mathrm{m}$. Thick albumen height $(\mathrm{AH})$ and yolk height $(\mathrm{YH})$ were measured to the nearest $\mathrm{mm}$. with a tripod micrometer

3- Fertility and hatchability: At 48-52, $52-56$ and $56-60$ weeks of age, eggs were collected. At each period age, egg collection continued until a total number of 90 eggs per each treatment had been collected after removing visibly dirty, misshapen or cracked eggs. Eggs for each treatment were placed into 3 trays (30 eggs per tray). Thereafter, eggs were fumigated for 20 min. with formaldehyde gas. The experiment was conducted using electronically controlled single-stage incubators (Petersime, Model 576). The temperature and humidity recommended by the incubator manufacturer were maintained. Fertility was estimated by the number of fertile eggs at the $8^{\text {th }}$ days of the incubation in percent of total number of eggs set. Hatchability was estimated by the number of healthy chicks hatched in percent of total number of fertile eggs set.

4- Proximate and statistical analysis: Chemical analysis of representative samples of the experimental diets was carried out in triplicate according to the standard methods outlined by A.O.A.C. (1980). Data obtained were statistically analyzed by a one way analysis of variance according to Steel and Torrie (1980) including analysis of variance. Also, SPSS computer statistical program for MS Windows release 6.0 June 1993 was used. Differences among means were tested using Duncan's Multiple Range Test (Duncan, 1955) with a $5 \%$ level .

\section{RESULTS AND DISCUSSION}

\section{Laying performance:}

The results obtained for laying hen performance in terms of egg weight (EW) egg number (EN), egg weight (EW), egg mass (EM), feed intake ( $F I)$ and feed conversion (FC) at 48-52, 52-56 and 56-60 weeks of age are shown in Table 2

During the period from 48 to 52 weeks of age, hens receiving pyridoxine-supplemented diet had significantly the highest EW, EN, EM and values. Layers consumed diets supplemented with folic acid had significantly better in EW, EM and FC as compared to control.

During the period from 52 to 56 weeks of age, it was noticed that hens received pyridoxine or folic acid supplemented diets had similar values of EW, $\mathrm{EN}, \mathrm{EM}, \mathrm{FI}$ and $\mathrm{FC}$ and both were significantly (P0.05) better than those of control.

During the period from 56 to 60 weeks of age, the results revealed that hens for all treatments showed the same trend observed during the period from 48 to 52 weeks of age. The only exception was for hens fed pyridoxinesupplemented diet that had significantly higher EN value than those fed either fed folic acid-supplemented or control diets that had similar values in this respect. During the whole experimental period (48- 60 weeks), the birds received folic acid or pyridoxine- supplemented diets had significantly (P0.05P better values of Ew,EM, FI and FC than those received the control diet. 
Table 2: Feed intake (kg/hen), Egg number, Egg weight (g), Egg mass $(\mathrm{kg})$ and Feed conversion of laying hens fed the experimental diets at 48-52, 52-56, 56-60 and 48-60 weeks of age.

\begin{tabular}{|c|c|c|c|}
\hline \multirow{2}{*}{ Items } & \multicolumn{3}{|c|}{ Treatments } \\
\hline & Control & Folic acid & Pyridoxine \\
\hline \multicolumn{4}{|c|}{ 48-52 wks. } \\
\hline Egg weight & $47.48 \pm 0.26^{c}$ & $50.50 \pm 0.06^{b}$ & $51.03 \pm 0.02^{\mathrm{a}}$ \\
\hline Egg number & $15.40 \pm 0.05^{\mathrm{b}}$ & $15.38 \pm 0.09^{b}$ & $15.81 \pm 0.01^{\mathrm{a}}$ \\
\hline Egg mass & $0.73 \pm 0.01^{c}$ & $0.79 \pm 0.01^{b}$ & $0.81 \pm 0.004^{a}$ \\
\hline Feed intake & $3.00 \pm 0.02^{b}$ & $3.00 \pm 0.02^{b}$ & $3.10 \pm 0.02^{\mathrm{a}}$ \\
\hline Feed conversion & $4.10 \pm 0.01^{\mathrm{a}}$ & $3.81 \pm 0.02^{\mathrm{b}}$ & $3.84 \pm 0.02^{b}$ \\
\hline \multicolumn{4}{|c|}{ 52-56 wks. } \\
\hline Egg weight & $47.67 \pm 0.86^{b}$ & $49.75 \pm 0.10^{\mathrm{a}}$ & $49.81 \pm .06^{a}$ \\
\hline Egg number & $14.43 \pm 0.08^{b}$ & $15.35 \pm 0.14^{a}$ & $15.28 \pm 0.09^{a}$ \\
\hline Egg mass & $0.71 \pm 0.01^{b}$ & $0.75 \pm 0.01^{a}$ & $0.74 \pm 0.01^{\mathrm{a}}$ \\
\hline Feed intake & $2.92 \pm 0.05^{a}$ & $2.95 \pm 0.04^{a}$ & $2.83 \pm 0.02^{\mathrm{a}}$ \\
\hline Feed conversion & $4.13 \pm 0.08^{a}$ & $3.91 \pm 0.03^{b}$ & $3.89 \pm 0.01^{\mathrm{b}}$ \\
\hline \multicolumn{4}{|c|}{ 56-60 wks. } \\
\hline Egg weight & $48.09 \pm 0.05^{c}$ & $49.01 \pm 0.06^{b}$ & $49.86 \pm 0.08^{a}$ \\
\hline Egg number & $13.98 \pm 0.09^{b}$ & $14.82 \pm 0.08^{a}$ & $14.79 \pm 0.20^{\mathrm{a}}$ \\
\hline Egg mass & $0.67 \pm 0.004^{c}$ & $0.70 \pm 0.004^{b}$ & $0.74 \pm 0.01^{\mathrm{a}}$ \\
\hline Feed intake & $2.77 \pm 0.02^{b}$ & $2.80 \pm 0.02^{\mathrm{b}}$ & $2.95 \pm 0.05^{\mathrm{a}}$ \\
\hline Feed conversion & $4.42 \pm 0.01^{a}$ & $4.00 \pm 0.02^{b}$ & $4.00 \pm 0.02^{b}$ \\
\hline \multicolumn{4}{|c|}{ 48-60 wks (overall period) } \\
\hline Egg weight & $47.75 \pm 0.09^{b}$ & $49.75 \pm 0.12^{a}$ & $50.23 \pm 0.07^{a}$ \\
\hline Egg number & $43.81 \pm 0.11^{b}$ & $45.55 \pm 0.10^{a}$ & $45.88 \pm 0.08^{a}$ \\
\hline Egg mass & $2.09 \pm 0.02^{b}$ & $2.27 \pm 0.01^{a}$ & $2.30 \pm 0.03^{a}$ \\
\hline Feed intake & $8.69 \pm 0.09^{b}$ & $8.75 \pm 0.07^{b}$ & $8.88 \pm 0.05^{a}$ \\
\hline Feed conversion & $4.16 \pm 0.03^{a}$ & $3.85 \pm 0.01^{\mathrm{b}}$ & $3.86 \pm 0.02^{b}$ \\
\hline
\end{tabular}

$a, b, c:$ means in the same row having different letters are significantly different at $p \leq 0.05$.

The improvement in the final EW and EN of hens fed folic acid or pyridoxine-supplemented diets in the current study during the overall experimental period agrees with those reported by Robel (1993) who mentioned that turkey egg weight was significantly increased with the increase of folic acid supplementation and disagree with the results of House et al., (2002) who found no significant difference due to folic acid supplementation on egg weight or production. Also, Keshavarz (2003) reported that certain manipulations of the combination of folic and other vitamins have the potential effect to reduce egg weight without affecting egg production.

The non-significant differences in FI between hens fed folic acid or control diets during the tested periods in the current study disagree with the results of House et al., (2002) who stated that feed consumption was slightly depressed at level of $4-16 \mathrm{mg}$ folic/kg intake. The increased final FI of hens fed pyridoxine-supplemented diets indicated that pyridoxine may improve the palatability of feed. 
Hatching parameters:

The results obtained for hatching parameters in terms of the percentages of infertile eggs $\%$, dead eggs $\%$, dead chicks $\%$, abnormal chicks $\%$, chick weight, fertility $\%$ and hatchability $\%$ at $48-52,52-56,56-60$ weeks 50,54 and 58 weeks of age are presented in Table 3.

At 48-52 weeks of age, it was noticed that hens fed pyridoxinesupplemented diet had significantly lower infertile eggs and hatchability percentages than those fed folic acid-supplemented diet. However, hens fed control diet gave the highest infertile Eggs \% and the lowest hatchability \%. The results also indicated that hens fed pyridoxine-supplemented diet had significantly higher dead eggs $\%$, dead chicks $\%$, chick weight and fertility \% values than those fed folic acid-supplemented diet. However, hens fed control diet gave the highest dead eggs and dead chicks values and the lowest chick weight and fertility values. Furthermore, hens fed control diet had significantly higher abnormal chicks \% than those fed either fed folic acid or pyridoxinesupplemented diets that had similar values in this respect.

Table 3: Hatching parameters \% for laying hens fed the experimental diets at 48-52, 52-56 and 56-60 weeks of age.

\begin{tabular}{|l|c|c|c|}
\hline \multirow{2}{*}{ Items } & \multicolumn{3}{|c|}{ Treatments } \\
\cline { 2 - 4 } & Control & Folic acid & Pyridoxine \\
\hline \multicolumn{3}{|c|}{$\mathbf{4 8 - 5 2}$ wks. } \\
\hline Infertile eggs\% & $5.92 \pm 0.09^{\mathrm{a}}$ & $5.39 \pm 0.12^{\mathrm{b}}$ & $5.07 \pm 0.09^{\mathrm{c}}$ \\
\hline Dead eggs\% & $5.62 \pm 0.09^{\mathrm{a}}$ & $2.76 \pm 0.08^{\mathrm{c}}$ & $4.07 \pm 0.28^{\mathrm{b}}$ \\
\hline Dead chicks\% & $1.80 \pm 0.02^{\mathrm{a}}$ & $1.09 \pm 0.03^{\mathrm{c}}$ & $1.18 \pm 0.02^{\mathrm{b}}$ \\
\hline Abnormal chicks\% & $1.31 \pm 0.05^{\mathrm{a}}$ & $0.66 \pm 0.03^{\mathrm{b}}$ & $0.71 \pm 0.05^{\mathrm{b}}$ \\
\hline Chick weight & $32.18 \pm 0.09^{\mathrm{c}}$ & $32.88 \pm 0.07^{\mathrm{b}}$ & $33.54 \pm 0.12^{\mathrm{a}}$ \\
\hline Fertility\% & $91.94 \pm 0.10^{\mathrm{c}}$ & $93.99 \pm 0.13^{\mathrm{b}}$ & $93.07 \pm 0.03^{\mathrm{a}}$ \\
\hline Hatchability\% & $82.05 \pm 0.49^{\mathrm{c}}$ & $86.11 \pm 0.04^{\mathrm{a}}$ & $84.06 \pm 0.22^{\mathrm{b}}$ \\
\hline \multicolumn{3}{|c|}{$\mathbf{5 2 - 5 6}$ wks. } \\
\hline Infertile eggs\% & $6.06 \pm 0.04^{\mathrm{a}}$ & $5.79 \pm 0.09^{\mathrm{b}}$ & $5.01 \pm 0.05^{\mathrm{c}}$ \\
\hline Dead eggs\% & $5.76 \pm 0.10^{\mathrm{a}}$ & $3.04 \pm 0.12^{\mathrm{b}}$ & $3.06 \pm 0.10^{\mathrm{b}}$ \\
\hline Dead chicks\% & $1.91 \pm 0.03^{\mathrm{a}}$ & $1.11 \pm 0.03^{\mathrm{b}}$ & $1.19 \pm 0.03^{\mathrm{b}}$ \\
\hline Abnormal chicks\% & $1.40 \pm 0.17^{\mathrm{a}}$ & $0.85 \pm 0.04^{\mathrm{b}}$ & $0.92 \pm 0.04^{\mathrm{b}}$ \\
\hline Chick weight & $32.01 \pm 0.14^{\mathrm{b}}$ & $32.20 \pm 0.26^{\mathrm{b}}$ & $33.21 \pm 0.25^{\mathrm{a}}$ \\
\hline Fertility\% & $92.00 \pm 0.10^{\mathrm{c}}$ & $92.97 \pm 0.05^{\mathrm{b}}$ & $93.41 \pm 0.05^{\mathrm{a}}$ \\
\hline Hatchability\% & $81.04 \pm 0.04^{\mathrm{c}}$ & $85.46 \pm 0.18^{\mathrm{a}}$ & $83.91 \pm 0.31^{\mathrm{b}}$ \\
\hline & $\mathbf{5 6}-60$ wks. \\
\hline Infertile eggs\% & $6.70 \pm 0.16^{\mathrm{a}}$ & $5.69 \pm 0.07^{\mathrm{b}}$ & $5.10 \pm 0.07^{\mathrm{c}}$ \\
\hline Dead eggs\% & $5.91 \pm 0.04^{\mathrm{a}}$ & $3.07 \pm 0.21^{\mathrm{b}}$ & $3.01 \pm 0.03^{\mathrm{b}}$ \\
\hline Dead chicks\% & $2.04 \pm 0.01^{\mathrm{a}}$ & $1.14 \pm 0.03^{\mathrm{b}}$ & $1.21 \pm 0.02^{\mathrm{b}}$ \\
\hline Abnormal chicks\% & $1.70 \pm 0.05^{\mathrm{a}}$ & $0.96 \pm 0.02^{\mathrm{b}}$ & $1.00 \pm 0.07^{\mathrm{b}}$ \\
\hline Chick weight & $32.02 \pm 0.12^{\mathrm{c}}$ & $32.46 \pm 0.19^{\mathrm{b}}$ & $33.06 \pm 0.13^{\mathrm{a}}$ \\
\hline Fertility\% & $92.04 \pm 0.01^{\mathrm{c}}$ & $92.80 \pm 0.12^{\mathrm{b}}$ & $93.27 \pm 0.08^{\mathrm{a}}$ \\
\hline Hatchability\% & $80.21 \pm 0.05^{\mathrm{c}}$ & $84.58 \pm 0.09^{\mathrm{a}}$ & $82.07 \pm 0.07^{\mathrm{b}}$ \\
\hline
\end{tabular}

$a, b, c:$ means in the same row having different letters are significantly different at $p \leq 0.05$ 
At 52-54 weeks of age, the layer fed pyridoxine supplemented diet had significantly (P0.05) the highest values of fertility percentage and followed by there of folic acid and than the control in a descenting order. However, the highest hatchability value was recorded for those of folic acid. The control group had the least values of the previously mentraned. Traids among all groups.

The improvement observed in fertility and hatchability of eggs produced from hens received folic acid or pyridoxine-supplemented diets as compared to those fed control diet in this study could be associated with the improvement in egg shell quality due to feeding folic acid or pyridoxinesupplemented diets. This is in accordance with the results of Ferguson et al., (1961) and Sirbu et al., (1981) who reported that hatchability and poult weight are related to folic acid in the egg and it is due to the role of folic acid in cellular development and higher supplementation of folic acid levels which could be required for rapid embryonic development. On other hand, of Roble (1993) reported that dietary supplemental folic acid levels produced a positive linear response pattern on the transfer of folic acid in eggs, but did not result in a hatchability increase. Also, Roble (1992) found that dietary supplementation of pyridoxine above the basal diet did not result in increasing hatchability. It is postulated that the notable chick abnormalities observed in hens fed control diet may be useful in diagnosing subclinical folic acid and/or pyridoxine deficiency.

\section{Egg quality:}

The results obtained for egg quality in terms of egg weight (EW), egg shape index \% (ESI), albumen \%, yolk \%, shell \%, shell thickness (ST), albumen height $(\mathrm{AH})$ and yolk height $(\mathrm{YH})$ at $48-52,52-56$ and $56-60$ weeks of age are shown in Table 4.

At 48-52 weeks of age, hens fed pyridoxine-supplemented diet had significantly the heaviest EW followed by hens fed folic acid-supplemented diet and then hens fed control diet. The results also indicated that hens fed folic acid diet had significantly higher ESI \% than those fed either fed pyridoxine-supplemented or control diets which more similar in this respect. The hens fed control diet had significantly lower yolk \%, shell \%, ST and YH than those fed either folic acid or pyridoxine-supplemented diets that had similar values in this respect. No significant differences were observed in both albumen $\%$ and $\mathrm{AH}$ due to treatment.

At 54 weeks of age, it was noticed that hens received pyridoxinesupplemented diet had similar EW values to those fed folic acidsupplemented diets. The results also showed the same trend observed at the period from 48 to 52 weeks of age concerning to other traits.

At 56-60 weeks of age, the results showed the same trend previously mentioned at 50 weeks of age at the first period (48-52weeks).

The superiority of hens receiving folic acid or pyridoxine-supplemented diets in respect of shell quality observed in the current study agree with the findings of Keshavarz (2003) who found that folic acid have the potential effect to improve shell quality. Moreover, there is a little information regarding the folic acid supplementation on egg quality characters. 
Wagdy, A.Z. et al.

Table 4: Egg quality traits of laying hens fed the experimental diets at 50,54 and 58 weeks of age.

\begin{tabular}{|c|c|c|c|}
\hline \multirow{2}{*}{ Items } & \multicolumn{3}{|c|}{ Treatments } \\
\hline & Control & Folic acid & Pyridoxine \\
\hline \multicolumn{4}{|c|}{$48-52$ wks. } \\
\hline Av. Egg wt. (g) & $47.61 \pm 0.16^{c}$ & $50.31 \pm 0.06^{b}$ & $51.13 \pm 0.12^{\mathrm{a}}$ \\
\hline Egg Shape Index (\%) & $77.03 \pm 0.99^{b}$ & $80.69 \pm 0.93^{a}$ & $77.01 \pm 0.87^{b}$ \\
\hline Albumen (\%) & $55.91 \pm 0.14^{\mathrm{a}}$ & $56.02 \pm 0.21^{a}$ & $56.05 \pm 0.19^{a}$ \\
\hline Yolk (\%) & $30.01 \pm 0.19^{b}$ & $33.38 \pm 0.14^{a}$ & $33.41 \pm 0.11^{\mathrm{a}}$ \\
\hline Shell (\%) & $10.44 \pm 0.08^{b}$ & $11.37 \pm 0.19^{a}$ & $11.48 \pm 0.11^{\mathrm{a}}$ \\
\hline Shell thickness (mm) & $4.07 \pm 0.06^{\mathrm{b}}$ & $4.53 \pm 0.10^{\mathrm{a}}$ & $4.46 \pm 0.17^{a}$ \\
\hline Albumen height & $7.07 \pm 0.17^{a}$ & $6.36 \pm 0.11^{\mathrm{a}}$ & $6.41 \pm 0.17^{a}$ \\
\hline Yolk height & $14.51 \pm 0.13^{b}$ & $15.75 \pm 0.10^{a}$ & $15.68 \pm 0.21^{\mathrm{a}}$ \\
\hline \multicolumn{4}{|c|}{ 52-56 wks. } \\
\hline Av. Egg wt. (g) & $47.27 \pm 0.09^{b}$ & $49.62 \pm 0.10^{\mathrm{a}}$ & $49.70 \pm .06^{a}$ \\
\hline Egg Shape Index & $77.50 \pm 0.39^{b}$ & $80.99 \pm 0.73^{a}$ & $77.22 \pm 1.18^{\mathrm{b}}$ \\
\hline Albumen (\%) & $56.69 \pm 1.28^{\mathrm{a}}$ & $56.77 \pm 1.15^{a}$ & $56.73 \pm 1.30^{\mathrm{a}}$ \\
\hline Yolk (\%) & $31.02 \pm 0.84^{b}$ & $32.48 \pm 0.76^{a}$ & $32.65 \pm 0.98^{a}$ \\
\hline Shell (\%) & $10.05 \pm 0.63^{b}$ & $10.95 \pm 0.41^{a}$ & $10.82 \pm 0.48^{\mathrm{a}}$ \\
\hline Shell thickness (mm) & $4.00 \pm 0.07^{\mathrm{b}}$ & $4.80 \pm 0.14^{\mathrm{a}}$ & $4.73 \pm 0.18^{a}$ \\
\hline Albumen height & $6.85 \pm 0.10^{\mathrm{a}}$ & $7.01 \pm 0.16^{\mathrm{a}}$ & $6.94 \pm 0.10^{a}$ \\
\hline Yolk height & $14.07 \pm 0.70^{\mathrm{b}}$ & $14.98 \pm 0.26^{a}$ & $15.06 \pm 0.10^{a}$ \\
\hline \multicolumn{4}{|c|}{ 56-60 wks. } \\
\hline Av. Egg wt. (g) & $48.09 \pm 0.05^{c}$ & $49.00 \pm 0.06^{b}$ & $49.93 \pm 0.08^{\mathrm{a}}$ \\
\hline Egg Shape Index & $77.13 \pm 1.28^{b}$ & $79.53 \pm 3.29^{a}$ & $77.10 \pm 0.91^{b}$ \\
\hline Albumen (\%) & $56.54 \pm 1.22^{\mathrm{a}}$ & $56.42 \pm 0.37^{a}$ & $56.73 \pm 0.91^{a}$ \\
\hline Yolk (\%) & $31.05 \pm 1.31^{b}$ & $34.04 \pm 0.13^{\mathrm{a}}$ & $33.68 \pm 0.73^{a}$ \\
\hline Shell (\%) & $10.02 \pm 0.15^{b}$ & $11.21 \pm 0.24^{a}$ & $11.18 \pm 0.28^{a}$ \\
\hline Shell thickness (mm) & $4.03 \pm 0.07^{b}$ & $4.60 \pm 0.06^{a}$ & $4.64 \pm 0.14^{a}$ \\
\hline Albumen height & $6.46 \pm 0.22^{a}$ & $6.73 \pm 0.19^{\mathrm{a}}$ & $7.14 \pm 0.17^{a}$ \\
\hline Yolk height & $14.01 \pm 0.14^{b}$ & $14.71 \pm 0.31^{a}$ & $14.83 \pm 0.20^{\mathrm{a}}$ \\
\hline
\end{tabular}

$a, b, c:$ means in the same row having different letters are significantly different at $p \leq 0.05$.

\section{REFERENCES}

A.O.A.C., (1980). Official Methods of Analysis Association of Official Analytical Chemists, 15 th Edition, Washington, D.C., USA.

Bender, D. A. (1989). Vitamin $\mathrm{B}_{6}$ requirements and recommendations. Eur $\mathrm{J}$ Clin Nutr; 43:289-309.

Chandra, R. and L. Sudhakaran (1990). Regulation of immune responses by Vitamin B6, NY Acad Sci 1990; 585:404-423.

Duncan, D. B.(1955). Multiple range and multiple $F$ tests.Biometrics, 11: 1-42.

Ferguson, T. M.; C. H. Whiteside; C. R. Creger; M. L. Jones; R. L. Atkinson and J. R. Couch. (1961). B-vitamin deficiency in the mature turkey hen. Poultry Sci., 40: 1153-1159. 
House, J. D.; K. Braun; D. M. Balance; C. P. O,Connor and W. Guenter. (2002). The enrichment of eggs with folic acid through supplementation of the laying hen diet. Poultry sci., 81: 1332-1337.

House. J. D.; R. L. Jacobs; L. M. Stead; M. E. Brosnan and J. T. Brosnan (1999). Regulation of homocystine metabolism. Adv. Enzyme Reg., 39: 69-91

Keshavarz, K. (2003). Effects of reducing dietary protein, methionine, choline, folic acid, and vitamin B12 during the late stages of the egg production cycle on performance and eggshell quality. Poultry sci., 82(9):1407-14.

Leklem, J. E., (1999). Vitamin B6 in: Shils ME, Olson JA, Shike M, Ross AC, ed, Moderwl Nutrition in Health and Disease, 9th ed. Baltimore: Williams and Wilkins, 413-421.

N. R. C., (1994). Nutrient Requirements of Poultry 9th ed, National Academy of Science, National Research Council. Washinton, D.C., U.S.A.

Robel, E. J. (1993). Evaluation of egg injection of folic acid and effect of supplement folic acid on hatchability and poult weight. Poultry sci., 72 (3): 546-553.

Robel, E. J. (1992). Effect of dietary supplemental pyridoxine levels on the hatchability of turkey eggs. Poultry sci., 71(10):1733-1738.

Ryu, K. S.; G. M. Pesti; K. D. Roberson; HM. Jr. Edwards; and R.R. Eitenmiller (1995). The folic acid requirements of starting broiler chicks fed diets based on practical ingredients. 2. Interrelationships with dietary methionine. Poult Sci.;74(9):1456-1462.

Shibata K; M. Mushiage; T. Kondo; T. tjayakawa and H. Tsuge (1995). Effects of vitamin $\mathrm{B}_{6}$ deficiency on the conversion ratio of tryptophan to niacin. Biosci Biotechnol Biochem; 59: 2060- 2063.

Sirbu, M.; C. Damian; E. Rotunjeanu and D. Turgu. (1981). Establishing the optimum level of folic acid in feeds for laying hens. Lucr. Stiint. Inst. Cerce. Pentru Nutr. Anim. 9/10: 153-160.

SPSS (1993). SPSS Statistical software Package for the social sciences. 2 nd ed. HA33- N48. McGrow-Hill, Inc., USA.

Steel, R. G. D. and J. H. Torrie (1980). Principles and procedures of statistics: A Biometrical 2 nd ed. McGraw-Hill Book Co., Inc., New York, USA.

Trakatellis. A.; A. Dimitriadou and M. Trakatelli (1997). Pyridoxine deficiency: New approaches in immunosuppression and chemotherapy. Postgrad Med J; 73: 617-622. 
Wagdy, A.Z. et al.

تحسين نسبة الفقس للبيض المتأخر الوضع بإضـافة كلا من حمضى البيرودوكسين

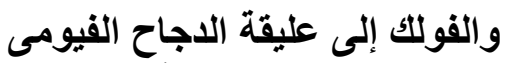

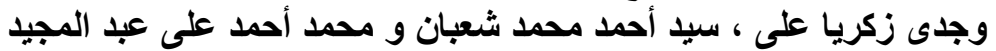
معهد بحوث الإتتاج الحيواني ـ مركز البحوث الزراعية ـ وزارة الزئراعة ـ الدقى ، جيزة ، مصر.

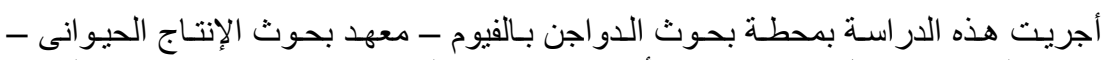

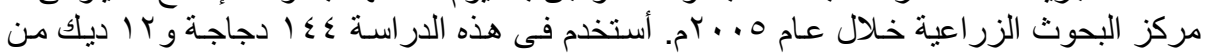

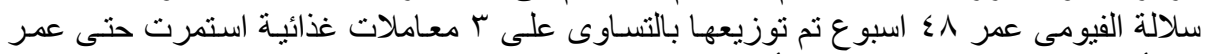

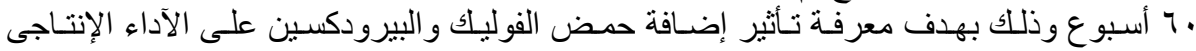
ونسبة الفقس لبيض الدجاج الفيومى.

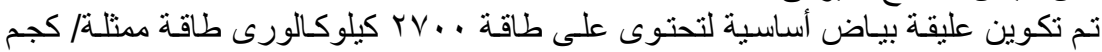

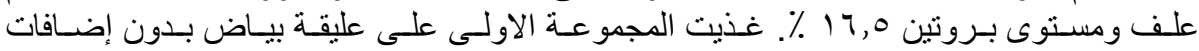

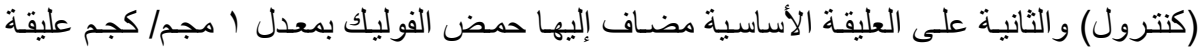

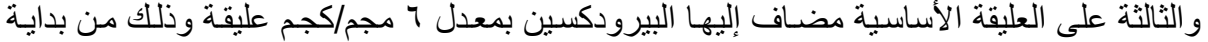

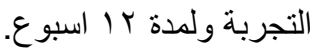

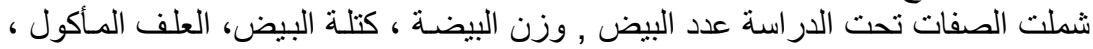

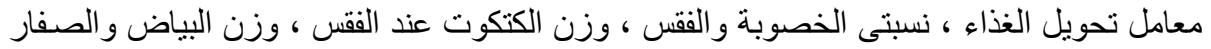

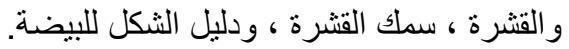

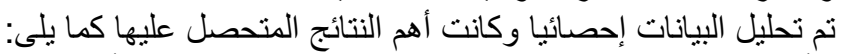

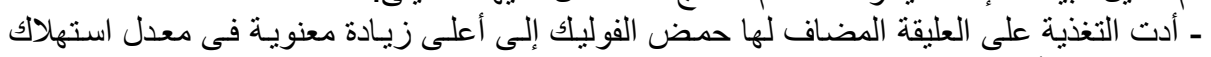

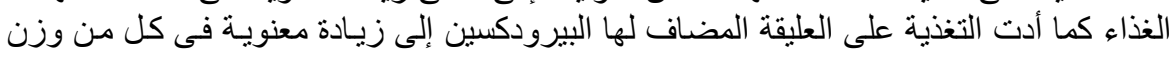

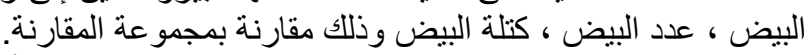

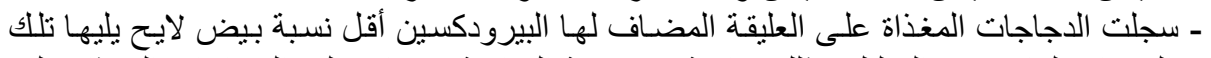

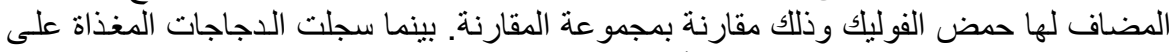

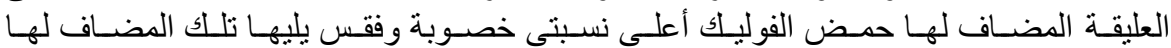

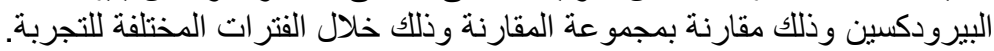

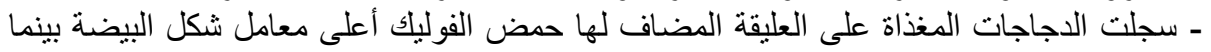

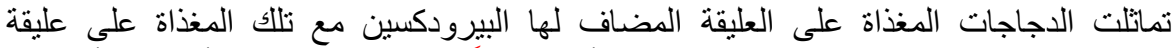

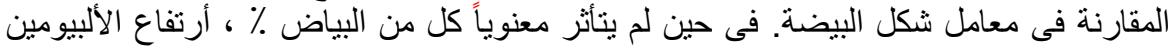

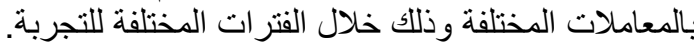

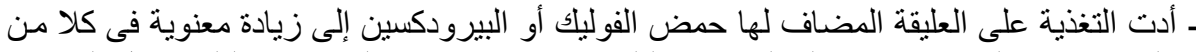

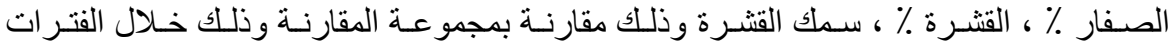

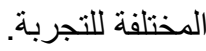

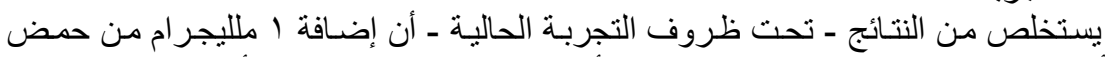

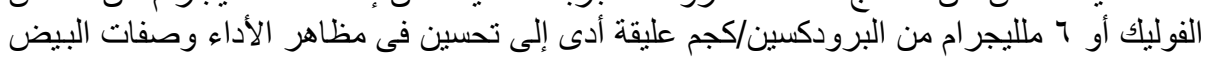
ونسبتى الخصوبة والفقس وذللك خلال الفترات المختلفة للتجربة. 